\title{
Secular change in TTG compositions: Implications for the evolution of Archaean geodynamics
}

\author{
T. E. Johnson ${ }^{1,2^{*}}$, C. L. Kirkland ${ }^{1 \dagger}$, N. J. Gardiner ${ }^{1 \dagger}$, M. Brown ${ }^{3}$, R. H. Smithies ${ }^{4}$, M. Santosh ${ }^{5,6}$
}

${ }^{1}$ School of Earth and Planetary Sciences, The Institute for Geoscience Research (TIGeR), $\left({ }^{\dagger}\right.$ CET - Curtin node), Curtin University, GPO Box U1987, Perth WA 6845, Australia. *e-mail: tim.johnson@ @urtin.edu.au

${ }^{2}$ Center for Global Tectonics, State Key Laboratory of Geological Processes and Mineral Resources, China University of Geosciences, Wuhan, Hubei Province, 430074, China.

${ }^{3}$ Laboratory for Crustal Petrology, Department of Geology, University of Maryland, College Park, MD 20742-4211, USA.

${ }^{4}$ Geological Survey of Western Australia, 100 Plain Street, East Perth, WA 6004, Australia.

${ }^{5}$ Centre for Tectonics, Resources and Exploration, Department of Earth Sciences, University of Adelaide, SA 5005, Australia

${ }^{6}$ School of Earth Sciences and Resources, China University of Geosciences, 29 Xueyuan Road, Beijing 100083, China.

${ }^{*}$ Corresponding author. Tel.: +61 89266 7332; fax: +61 89266 3153. E-mail address:tim.johnson@curtin.edu.au (T.E.Johnson).

${ }^{*}$ Current address: Department of Earth, Atmosphere and Environment, Monash University, Victoria 3800, Australia. 


\section{ABSTRACT}

It is estimated that around three quarters of Earth's first generation continental crust had been produced by the end of the Archaean Eon, 2.5 billion years ago. This ancient continental crust is mostly composed of variably deformed and metamorphosed magmatic rocks of the tonalitetrondhjemite-granodiorite (TTG) suite that formed by partial melting of hydrated mafic rocks. However, the geodynamic regime under which TTG magmas formed is a matter of ongoing debate. Using a filtered global geochemical dataset of 563 samples with ages ranging from the Eoarchaean to Neoarchaean $(4.0-2.5 \mathrm{Ga})$, we interrogate the bulk rock major oxide and trace element composition of TTGs to assess evidence for secular change. Despite a high degree of scatter in the data, the concentrations or ratios of several key major oxides and trace elements show statistically significant trends that indicate maxima, minima and/or transitions in the interval 3.3-3.0 Ga. Importantly, a change point analysis of $\mathrm{K}_{2} \mathrm{O} / \mathrm{Na}_{2} \mathrm{O}, \mathrm{Sr} / \mathrm{Y}$ and $\mathrm{La}_{\mathrm{N}} / \mathrm{Yb}_{\mathrm{N}}$ demonstrates a statistically significant (>99\% confidence) change during this 300 Ma period. These shifts may be linked to a fundamental change in geodynamic regime around the peak in upper mantle temperatures from one dominated by non-uniformitarian, deformable stagnant lid processes to another dominated by the emergence of global mobile lid or plate tectonic processes by the end of the Archaean. A notable change is also evident at 2.8-2.7 Ga, which coincides with a major jump in the rate of survival of metamorphic rocks with contrasting thermal gradients, which may relate to the emergence of more potassic continental arc magmas and an increased preservation potential during collisional orogenesis. In many cases, the chemical composition of TTGs shows an increasing spread through the Archaean, reflecting the irreversible differentiation of the lithosphere. 
Keywords: Archaean; geodynamics; mantle temperature; secular change; tonalite-trondhjemitegranodiorite (TTG) suite

\section{Introduction}

Much of Earth's continental crust was produced during the Archaean Eon, 4.0-2.5 billion years ago, forming the ancient cratonic nuclei, although a large proportion of this crust has since been recycled back into the mantle (Belousova et al., 2010; Dhuime et al., 2012; Hawkesworth et al., 2010). Exposed Archaean continental crust is dominantly composed of deformed and metamorphosed sodic granitoids of the tonalite-trondhjemite-granodiorite (TTG) suite. TTGs were produced by partial melting of relatively low-MgO hydrated basaltic rocks (amphibolites; (Foley et al., 2002; Johnson et al., 2014), and represent first-generation continental crust. Understanding how TTGs formed throughout the Archaean is to comprehend much about the origin and evolution of Earth's continental crust.

Most TTGs formed at pressures sufficiently high to stabilise garnet (Moyen, 2011), requiring minimum melting depths of around $20 \mathrm{~km}$ (Johnson et al., 2017). Some consider that TTGs formed mainly by partial melting of subducting oceanic lithosphere in a process analogous to the formation of modern-day adakites (Arndt, 2013; Drummond and Defant, 1990; Foley et al., 2002; Martin, 1999; Martin and Moyen, 2002; Polat et al., 2015). Others favour nonuniformitarian models, at least in the early Archaean, in which TTGs formed in the lower levels of thick ( $>30 \mathrm{~km})$ plateau-like mafic crust following protracted multistage reworking of primitive 
high-MgO primary crust (Bédard, 2006; Johnson et al., 2014, 2017; Kamber, 2015; Sizova et al., 2015; Smithies, 2000, 2003; Van Kranendonk et al., 2015a).

A fundamental control on geodynamics is the rheology of the lithosphere, which is strongly dependent on the temperature of the mantle, commonly expressed as the mantle potential temperature, $T_{\mathrm{p}}$ (Herzberg et al., 2010; Putirka, 2016). Petrological modelling of tholeiitic basalts (as a proxy for ambient mantle temperatures) and plume-related rocks such as komatiites implies that mantle temperatures were up to $250{ }^{\circ} \mathrm{C}$ warmer in the Archaean compared with the present day (Herzberg et al., 2010; Putirka, 2016), consistent with thermal models that suggest $T_{\mathrm{p}}$ may have peaked at around 3.0 Ga (Labrosse and Jaupart, 2007).

Although there is evidence for localised episodes of some form of subduction in the early Archaean (Jenner et al., 2009; O'Neil et al., 2011; Turner et al., 2014), melting in the lower levels of a thick, deformable, more-or-less continuous mafic crust (deformable stagnant lid or plutonic squishy lid regime) is arguably a more likely setting for formation of most TTG magmas, at least before the Mesoarchaean (Gardiner et al., 2017; Johnson et al., 2014, 2017; Rozel et al., 2017; Sizova et al., 2015; Smithies et al., 2003, 2007; Van Kranendonk et al., 2015a). Importantly, the existence of different geodynamic environments on Earth at any point in time is to be expected considering that the upper mantle temperature may have varied around the globe by $120^{\circ} \mathrm{C}$ or more in the Archaean, as it does today (Herzberg et al., 2007). Nevertheless, there is a growing consensus that some form of subduction became the dominant mechanism of lithospheric recycling at some time during the late Archaean (Hawkesworth and Brown, 2018; Korenaga, 2013).

Regional studies report field, structural, geochemical and/or geophysical data that have been used to support interpretations of convergent margin processes from as early as the late 
Eoarchaean in Greenland, from 3.5 Ga in the Kaapvaal Craton (Southern Africa), from 3.2-3.1

Ga in the Pilbara Craton (Western Australia) and southern India, and during the Neoarchean in the Superior Province of North America and the North China Craton (Calvert et al., 1995; Cawood et al., 2006; de Wit et al., 2018; Friend and Nutman, 2005; Kusky et al., 2016; Santosh et al., 2015; Smithies et al., 2007; Van Kranendonk et al., 2015b). On a global scale, statistical analysis of the chemical composition of continental igneous rocks with ages spanning $3.8 \mathrm{Ga}$ to the present day reveals patterns consistent with secular cooling of the mantle since the late Archaean (Keller and Schoene, 2012). The zircon record and the median $\mathrm{Rb} / \mathrm{Sr}$ ratios and $\mathrm{SiO}_{2}$ contents of crustal rocks have been attributed to the widespread appearance of subduction at around 3.0 Ga (Dhuime et al., 2012, 2015, 2017; Tang et al., 2016). This is consistent with the widespread survival of metamorphic rocks with contrasting thermal gradients since the Neoarchean that may indicate the beginning of subduction and consequent collisional orogenesis at that time, although there is little evidence before the Neoproterozoic for the cold collision and deep subduction of continental crust that characterises the modern plate tectonic regime (Brown and Johnson, 2018). In summary, there is a growing body of evidence that the continental lithosphere was stabilised in the Mesoarchean during a transition to some form of global plate tectonic regime.

The changing chemical composition of TTGs potentially provides a window into secular change of mantle temperatures and geodynamics during the Archaean. Based largely on the $\mathrm{SiO}_{2}$ content and $\mathrm{Mg} \#\left[\mathrm{Mg} \#=100 *\right.$ molecular $\left.\mathrm{Mg} /\left(\mathrm{Mg}+\mathrm{Fe}^{2+}\right)\right]$ of Archaean TTGs and modern (Cenozoic) adakites, Smithies (2000) found no geochemical evidence for subduction prior to $c a$ 3.0 Ga, although he did identify a clear contribution from a mantle component in some Neoarchaean TTGs from the Superior Province of Canada. Using a large dataset of whole rock 
chemical analyses of (meta)granitoid rocks with crystallization ages spanning the Archaean, Martin and Moyen (2002) also noted an overall increase in $\mathrm{Mg \#}$, along with $\mathrm{Ni}, \mathrm{Cr}, \mathrm{Sr}$ and $\mathrm{Na}_{2} \mathrm{O}$ $+\mathrm{CaO}$, with decreasing age from 4.0-2.5 Ga. Increases in $\mathrm{Mg \# ,} \mathrm{Ni}$ and $\mathrm{Cr}$ were interpreted by these authors to record an increasing degree of interaction of ascending TTG magmas with the mantle wedge, whereas increases in $\mathrm{Sr}$ and $\mathrm{Na}_{2} \mathrm{O}+\mathrm{CaO}$ were considered to reflect a successive reduction and eventual absence of plagioclase in the TTG source rocks, consistent with an increasing depth of melting (Martin and Moyen, 2002; Smithies, 2000). Thus, these compositional indicators were interpreted within a uniformitarian framework in which secular cooling of the upper mantle drove the onset of melting of the downgoing slab to successively deeper levels (Martin and Moyen, 2002). However, basaltic source rocks for some Paleoarchaean TTGs are unlikely to have crystallised from primary mantle melts, but were themselves derived via protracted reworking of existing crust along apparent geotherms that were much warmer than can be reasonably ascribed to a subduction setting (Johnson et al., 2017). In addition, the episodicity in the age distribution of Archaean continental crust (Fig. 1) may in part reflect enhanced periods of juvenile magmatism, at least locally, rather than simply enhanced preservation during collision (Condie et al., 2018; Hawkesworth et al., 2018). If this was the case, it is inconsistent with a supra-subduction origin for TTG magmas, in particular in the early Archaean when evidence for significant juvenile input is generally lacking (Gardiner et al., 2017; Naeraa et al., 2012; Walzer and Hendel, 2013).

Here we re-evaluate the secular change recorded in the major and trace element composition of TTGs using published whole rock data from samples with ages ranging from the Eoarchaean to the Neoarchaean. We apply simple quadratic and/or linear fits along with more sophisticated time series and change point analysis to evaluate the evidence for statistically 
meaningful changes in TTG compositions with time. Where such relationships exist, we interpret these changes within the context of the secular evolution of mantle temperature and the rheology of the lithosphere that ultimately led to subduction and the emergence of global plate tectonics during the late Archaean.

\section{Methods}

The whole rock geochemical dataset for TTGs used in this study is a subset of a larger published global dataset of Archaean (meta)granitoids [ $n=431$ of 1098 from Moyen (2011)] augmented with analyses of (mainly older) Archaean felsic rocks from the Pilbara Craton, Western Australia ( $n=73$; GSWA), the Yilgarn Craton, Western Australia ( $n=15$; GSWA), southwest Greenland ( $n=24$; Hoffmann et al., 2011, 2014) and the Acasta Gneiss Complex, Northwest Territories, Canada ( $n=20$; Reimink et al., 2016). We only consider samples for which crystallisation ages are known, mainly via $\mathrm{U}-\mathrm{Pb}$ dating of magmatic zircon. Although there is no strict quantitative compositional definition of TTG, to eliminate more evolved granitic rocks (sensu stricto), and sanukitoids and felsic cumulate rocks, we only consider those samples with $\mathrm{SiO}_{2} \geq 65 \%, \mathrm{~K}_{2} \mathrm{O} / \mathrm{Na}_{2} \mathrm{O} \leq 0.8$ and $\mathrm{Sr} / \mathrm{Y} \geq 30$. We have also excluded from the Moyen (2011) dataset the gneiss samples of Garde (1997) with assumed ages of $3.11 \mathrm{Ga}$, as the age of these rocks is uncertain and the assumed age is very poorly represented in the spectrum of magmatic U-Pb zircon ages (e.g. Roberts and Spencer, 2014).

The final TTG dataset used in this study comprises 563 samples with magmatic ages spanning 3.8-2.5 Ga, the age (in 20 million year bins) and locations (in terms of craton or 
cratonic fragment) of which are shown in Fig. 1. Of these samples, 28 are Eoarchaean (>3.6 Ga), 154 are Paleoarchaean (3.6-3.2 Ga), 153 are Mesoarchaean (3.2-2.8 Ga), and 228 are Neoarchaean $(2.8-2.5 \mathrm{Ga})$ in age (the dataset is given in Supplementary Data Table 1). A probability density function for these data (Fig. 1) shows pronounced peaks at 3.50-3.45 Ga, 3.25-3.20 Ga, 2.75-2.70 Ga, and 2.55-2.50 Ga, less pronounced peaks at 3.75-3.70 Ga and $\mathrm{ca}$ 3.00 Ga, and clear minima at $c a 3.65 \mathrm{Ga}, 3.35 \mathrm{Ga}, 3.10 \mathrm{Ga}$ and $2.60 \mathrm{Ga}$.

Plots of selected major oxides, Mg\# and major oxide ratios versus age are shown in Fig. 2. Plots of selected trace elements and trace element ratios [some normalised against the composition of CI chondrite from McDonough and Sun (1995)] versus age are shown in Fig. 3. As many samples contain analyses of only a restricted set of trace elements, the data density varies from plot to plot. In each case, individual data points are superimposed on smoothed kernel density estimates of the data - the blue 'clouds' - that simply reflect the density of data in compositional-time space. We focus on those major oxides, trace elements and/or ratios considered to have particular significance for TTG petrogenesis, in particular in terms of characterising: (i) the degree of partial melting of their source rocks (e.g. using $\mathrm{K}_{2} \mathrm{O}$ contents or $\mathrm{K}_{2} \mathrm{O} / \mathrm{Na}_{2} \mathrm{O}$ ratios); (ii) the presence of particular minerals, for example garnet, plagioclase, hornblende or rutile, in the source rock residues (e.g. using $\mathrm{Sr} / \mathrm{Y}, \mathrm{La} / \mathrm{Yb}, \mathrm{Zr} / \mathrm{Sm}, \mathrm{Nb} / \mathrm{Ta}$ or $\mathrm{Th} / \mathrm{Nb}$ ratios) from which the depth of partial melting is commonly inferred; and (iii) the degree of any interaction of the TTG melts with the mantle (e.g. using Ni or Cr), all of which have consequences for the geodynamic environment in which the TTG magmas formed (Drummond and Defant, 1990; Foley et al., 2002; Martin and Moyen, 2002; Moyen, 2011).

Initially, we are concerned with whether or not there is a temporal maximum or minimum in the data and/or any gradual change with time. To establish whether any statistically significant 
maximum or minimum exists, we first apply a quadratic fit of the form $y=a+b x+c x^{2}$, where $y$ is the concentration of an element/oxide or a ratio between elements/oxides, and $x$ is time. Statistical significance is assessed based on calculated $P$ values. For each of the quadratic terms (a, b and c), a calculated $P$ value $\leq 0.05$ falsifies the null hypothesis that this term has no statistical significance. A quadratic fit (solid black line in Figs $2 \& 3$ ) is shown in data plots where $P$ values for both the $\mathrm{b}$ and $\mathrm{c}$ terms are $\leq 0.05$. In cases where either (or both) of these values exceed 0.05 , we show a simple linear fit of the form $y=a+b x$ (dotted black line in Figs 2 $\& 3$ ) only where the $P$ value for the $\mathrm{b}$ term (the slope) is $\leq 0.05$. If $P$ values for both quadratic (b and/or c term) and linear fits (b term) exceed 0.05, no fit is shown. Where statistically meaningful fits exist, we show the associated mean prediction bands at a $95 \%$ confidence level (white bands in Figs $2 \& 3$ ). In all plots, we also show time series data examining any evidence for more complex changes. In each case, the solid red line shows the moving median of the data calculated every 20 Myr using a 0.2 Gyr moving window.

\section{Results}

\subsection{Major oxides}

Most TTG compositions in the dataset have $<75 \mathrm{wt} \% \mathrm{SiO}_{2}$ (not shown), for which there is no meaningful trend with age. For $\mathrm{TiO}_{2}$ contents (mostly between 0.2 and $0.6 \mathrm{wt} \%$ ), there is no statistically meaningful linear or quadratic fit to the data, but the moving median falls to a minimum at $c a 3.2 \mathrm{Ga}$ (Fig. 2a). Concentrations of $\mathrm{Al}_{2} \mathrm{O}_{3}$ (mostly between 14 and $17 \mathrm{wt} \%$ ) show 
a linear fit in which average concentrations reduce slightly with decreasing age, whereas the overall spread in the data increases (Fig. 2b). Concentrations of both $\mathrm{FeO}_{\mathrm{T}}$ (mostly $1-4 \mathrm{wt} \%$, considering all Fe as FeO; Fig. 2c) and $\mathrm{MgO}$ (mostly <2 wt\%; Fig. 2d) define weak trends of increasing concentration with decreasing age. The moving median for $\mathrm{FeO}_{\mathrm{T}}$ defines a minimum at $c a 3.2 \mathrm{Ga}$. A plot of Mg\# (mostly 40-60) against time shows a statistically meaningful peak at ca $2.9 \mathrm{Ga}$ (Fig. 2e). $\mathrm{K}_{2} \mathrm{O}$ contents, which exhibit a wide degree of scatter up to $4 \mathrm{wt} \%$, show no statistically significant linear or quadratic fit, although notably the moving median is generally higher after 3.0 Ga than before and the range in concentrations increases with decreasing age (Fig. 2f). Concentrations of $\mathrm{Na}_{2} \mathrm{O}$ show a clear decrease with decreasing age (on average from $\sim 5.5 \mathrm{wt} \%$ to $\sim 4.5 \mathrm{wt} \%$; Fig. $2 \mathrm{~g}$ ), whereas the ratio of $\mathrm{K}_{2} \mathrm{O} / \mathrm{Na}_{2} \mathrm{O}$ (Fig. $2 \mathrm{~h}$ ) shows a statistically significant minimum (with values of $\sim 0.3$ ) at $c a 3.3$ Ga. Finally, a plot of the aluminium saturation index $\left[\mathrm{ASI}=\right.$ molecular $\mathrm{Al}_{2} \mathrm{O}_{3} /\left(\mathrm{CaO}+\mathrm{Na}_{2} \mathrm{O}+\mathrm{K}_{2} \mathrm{O}\right]$ indicates that the TTGs have compositions that straddle the boundary between peraluminous and metaluminous and define a maximum (i.e. highest peraluminosity) at around $3.2 \mathrm{Ga}$ (Fig. 2i).

\subsection{Trace elements}

Ni contents (Fig. 3a) show wide variability, but define a linear trend increasing from an average of $\sim 9 \mathrm{ppm}$ at $3.8 \mathrm{Ga}$ to $\sim 16 \mathrm{ppm}$ at $2.5 \mathrm{Ga}$. Notably, the range of Ni concentrations increases significantly with decreasing age. A similar linear increase in average values and an increase in the spread of concentrations with decreasing age is shown by Ba (mostly <1500 ppm; Fig. 3b). Sr contents (mostly <1000 ppm; Fig. 3c) are not associated with any simple statistically meaningful fits. However, like $\mathrm{Ni}$ and $\mathrm{Ba}$, the range of $\mathrm{Sr}$ concentrations increases significantly with decreasing age, within which the kernel density estimate defines a cloud of decreasing $\mathrm{Sr}$ 
concentrations with decreasing age from around 3.5 to $2.7 \mathrm{Ga}$ (Fig. 3c). The moving median for Sr shows minima at $c a 3.7 \mathrm{Ga}$ and $c a 3.1 \mathrm{Ga}$. Similarly, there are no statistically meaningful linear or quadratic fits for $\mathrm{La}_{\mathrm{N}} / \mathrm{Yb}_{\mathrm{N}}$ (elemental values normalised against $\mathrm{CI}$ chondrite) or $\mathrm{Eu} / \mathrm{Eu}{ }^{*}$ with age. However, the moving median for $\mathrm{La}_{N} / \mathrm{Yb}_{\mathrm{N}}$ shows a minimum at around $3.2 \mathrm{Ga}$ (Figs 2d, e). Although data are relatively scarce, particularly for $\mathrm{Ta}$, the quadratic fit to the $\mathrm{Nb} / \mathrm{Ta}$ ratios defines a clear minimum between 3.3 and 3.2 Ga (Fig. 3f). Notwithstanding that the $\mathrm{Sr} / \mathrm{Y}$ ratios show a high degree of scatter and no simple linear or quadratic fits, the range of values increases with decreasing age and the moving median defines a minimum at $c a 3.35 \mathrm{Ga}$, rising to much higher values at 3.2-3.15 Ga (Fig. 3g). The $\mathrm{Zr} / \mathrm{Sm}$ ratio also shows no meaningful trend with age, although the spread of data increases with decreasing age (Fig. 3h). Importantly, with the exception of one datum in the Paleoarchaean and another in the Mesoarchaean, the only data with $\mathrm{Zr} / \mathrm{Sm}$ values lower than primitive mantle $[\mathrm{Zr} / \mathrm{Sm}<25.2$, shown as the horizontal dashed line (Sun and McDonough, 1989)] are Neoarchaean in age ( $n=16$; Fig. 3h). The quadratic fit to the $\mathrm{Th} / \mathrm{Nb}$ ratios shows a statistically meaningful minimum between 3.3 and $3.2 \mathrm{Ga}$, and the moving median for these data defines a minimum at ca $3.05 \mathrm{Ga}$ (Fig. 3i). Using the calibration of Boehnke et al. (2013), calculated $\mathrm{Zr}$ saturation temperatures $\left(T_{\mathrm{Zr}}\right)$ are mostly $<800{ }^{\circ} \mathrm{C}$ and define a linear trend with decreasing age (not shown) in which $T_{\mathrm{Zr}}$ decreases slightly from around 720 ${ }^{\circ} \mathrm{C}$ at $3.8 \mathrm{Ga}$ to around $690^{\circ} \mathrm{C}$ at $2.5 \mathrm{Ga}$.

\subsection{Change point analysis - step changes in the Earth system}

To further assess evidence for significant shifts in the data, and determine the most likely age, magnitude, and statistical confidence bounds associated with any such shifts, we use a 
cumulative sum (CUSUM) change-point analysis on selected geochemical discriminants based on a mean shift model (Mustonen et al., 2012). This approach has previously been applied to oxygen isotopes in zircons from the Pilbara Craton to assess evidence for increased crustal recycling at ca $3.2 \mathrm{Ga}$ (Van Kranendonk et al., 2015b). For each data point, the CUSUM is calculated by summing all the values within the time series, with the first cumulative sum set to zero. Subsequent cumulative sums in the time series are considered by adding the difference between the current value and the average to the previous sum and visualized on a CUSUM chart (Fig. 4). A segment of the CUSUM chart with an upward slope indicates a period where the values tend to be above the overall average and vice versa. A sudden change in direction of the CUSUM indicates a sudden shift or change in the average, whereas periods during which the CUSUM chart follows a relatively straight path indicate a period where the average changed little. A confidence interval on shifts within the dataset is calculated by bootstrapping, involving random reordering of the data to mimic the behaviour of the CUSUM value-performing a large number of bootstrap samples allows an estimate on the change in CUSUM for a condition of no change. Values in excess of the bootstrapped random trail indicate that a change has not occurred by chance alone. Bootstrapping results in a distribution-free approach with a single assumption, that of an independent error structure.

The CUSUM charts for $\mathrm{K}_{2} \mathrm{O} / \mathrm{Na}_{2} \mathrm{O}, \mathrm{Sr} / \mathrm{Y}$ and $\mathrm{La}_{\mathrm{N}} / \mathrm{Yb}_{\mathrm{N}}$ (Fig. 4a, b \& c, respectively), which are commonly used as discriminants to elucidate TTG petrogenesis, suggest that the period 3.3-3.0 Ga is important, marking an episode during which statistically significant (>99\%) change occurred. Within this time span, the CUSUM values (which are not equivalent to the measured values of the discriminant in question) for $\mathrm{K}_{2} \mathrm{O} / \mathrm{Na}_{2} \mathrm{O}$ increase sharply from a near minimum value at ca $3.3 \mathrm{Ga}$ to the maximum value at $c a 3.1 \mathrm{Ga}$. For $\mathrm{Sr} / \mathrm{Y}$ the opposite trend is 
observed, and the period 3.3-3.1 Ga includes both the maximum and minimum CUSUM values and a step function to significantly lower values with decreasing age close to $3.1 \mathrm{Ga}$. The plot for $\mathrm{La}_{\mathrm{N}} / \mathrm{Yb}_{\mathrm{N}}$ shows CUSUM values increasing across a 'plateau' over the period 3.3-3.0 Ga, with a maximum value at ca $3.0 \mathrm{Ga}$. In summary, statistically significant change in the $\mathrm{K}_{2} \mathrm{O} / \mathrm{Na}_{2} \mathrm{O}, \mathrm{Sr} / \mathrm{Y}$ and $\mathrm{La}_{\mathrm{N}} / \mathrm{Yb}_{\mathrm{N}}$ values occurs across the period 3.3 to $3.0 \mathrm{Ga}$, which is marked by the grey band in Fig. 4.

\section{Discussion}

Modern (Phanerozoic) juvenile mafic volcanic rocks from known tectonic settings have distinct compositions, reflecting their derivation by: (i) partial melting at depth of fertile undepleted mantle (e.g. to produce ocean island basalts or continental rift basalts); (ii) partial melting of dry depleted upper mantle (i.e. to produce mid ocean ridge basalt, or MORB) and; (iii) fluid-fluxed melting of the mantle wedge in suprasubduction zone settings (to produce oceanic and continental arc rocks). By contrast, mafic igneous rocks of Archaean age generally have compositions intermediate between those produced by these three end-member scenarios (Moyen and Laurent, 2017), suggesting that: (a) Archaean mafic rocks, at least those that formed in the early Archaean, were sourced from a mantle that was much less differentiated (i.e. neither very depleted nor enriched) than that of the modern Earth (Condie et al., 2016), and; (b) the Archaean Earth was characterised by a geodynamic regime in which the dominant tectonic environments were different, most notably lacking any clear distinction between the 'arc' and 'non-arc' settings that are characteristic of the modern Earth (Moyen and Laurent, 2017). 
Archaean TTGs represent ancient first generation continental crust that was derived by partial melting of long-lived hydrated basaltic crust (Gardiner et al., 2017; Johnson et al., 2017; Moyen and Laurent, 2017). The chemical composition of TTGs reflects: (i) the composition of their mafic source rocks; (ii) the degree of partial melting of the source rocks; (iii) the depth of melting of the source rocks, (iv) fractionation of the TTG magmas during ascent and emplacement; (v) contamination of the TTG magmas with their mantle and/or crustal host rocks during ascent and emplacement; and (vi) post-emplacement processes, potentially including high-grade crustal metamorphism and partial melting. In turn, these fundamental controls are a function of, among other things, the geothermal gradient and the availability and composition of fluids, all of which may change gradually, episodically or cyclically.

As a consequence of some or all of these processes, the geochemical signals encoded in TTGs, which reflect the geodynamic setting in which the magmas (and/or their source rocks) formed, are difficult to disentangle. Despite these complications, some patterns are evident that are statistically, and probably geologically, meaningful.

\subsection{Secular change in TTG compositions and the role of fractionation}

Notwithstanding that there are concerns regarding the robustness of $P$ values in evaluating scientific hypotheses (Baker, 2016), this test when applied to the dataset of TTG rock compositions suggests that some discriminants, in particular $\mathrm{K}_{2} \mathrm{O} / \mathrm{Na}_{2} \mathrm{O}, \mathrm{ASI}, \mathrm{Nb} / \mathrm{Ta}$ and $\mathrm{Th} / \mathrm{Nb}$, show statistically meaningful minima or maxima in the interval ca 3.3-3.0 Ga (Figs 2 \& 3). Although the variations are modest, minima are also evident when plotting the moving median 
for some of the geochemical proxies we consider, in particular $\mathrm{TiO}_{2}, \mathrm{FeO}_{\mathrm{T}}, \mathrm{MgO}, \mathrm{K}_{2} \mathrm{O} / \mathrm{Na}_{2} \mathrm{O}$, $\mathrm{La}_{\mathrm{N}} / \mathrm{Yb}_{\mathrm{N}}, \mathrm{Eu} / \mathrm{Eu}^{*}, \mathrm{Th} / \mathrm{Nb}$ and, when excluding the (scarce) data older than $3.6 \mathrm{Ga}, \mathrm{K}_{2} \mathrm{O}$ and $\mathrm{Sr}$. Other major oxide and trace element compositions and/or ratios exhibit statistically meaningful linear trends, most notably $\mathrm{MgO}, \mathrm{Ni}$ and $\mathrm{Ba}$, which all increase with decreasing age, and $\mathrm{Na}_{2} \mathrm{O}$ that (along with $\mathrm{Zr}_{\mathrm{T}}$ ) decreases (Figs 2 and 3).

It is likely that most TTGs underwent some degree of fractionation, involving crystallisation of hornblende and/or plagioclase as the TTG magmas ascended and cooled (Martin and Moyen, 2002). Furthermore, we cannot exclude the possibility that some TTGs in the dataset may have partially melted due to subsequent high-grade metamorphism. In both of these cases, average/median compositions may not be as useful in discriminating the petrogenesis of the magmas as the maximum values (for oxides/elements/ratios with bulk mineral/melt partition coefficients $>$ or $>>1$, and therefore compatible in the residua) or minimum values (for discriminants with bulk mineral/melt partition coefficients $<$ or $<<1$ ). For example, using partition coefficients appropriate for partial melting of amphibolite (table 1 of Bédard, 2006), different mixtures of residual plagioclase and hornblende will generally result in a decrease in $\mathrm{Mg \#}$, $\mathrm{Ni}, \mathrm{Sr}, \mathrm{Sr} / \mathrm{Y}$ and an increase in $\mathrm{Ba}, \mathrm{K}_{2} \mathrm{O}, \mathrm{K}_{2} \mathrm{O} / \mathrm{Na}_{2} \mathrm{O}$ and $\mathrm{Zr} / \mathrm{Sm}$ in the evolved melts. Consequently, the highest values of $\mathrm{Mg \#}, \mathrm{Ni}, \mathrm{Sr}, \mathrm{Sr} / \mathrm{Y}$ and $\mathrm{La}_{\mathrm{N}} / \mathrm{Yb}_{\mathrm{N}}$, and the lowest values of $\mathrm{Ba}, \mathrm{K}_{2} \mathrm{O}, \mathrm{K}_{2} \mathrm{O} / \mathrm{Na}_{2} \mathrm{O}$ and $\mathrm{Zr} / \mathrm{Sm}$ may be regarded as being representative of the most primitive TTG magmas (i.e. those reflecting the highest degrees of partial melting and/or the lowest degrees of fractional crystallization), which may most clearly preserve evidence for the original source characteristics and petrogenetic processes. The highest or lowest values correspond to the upper and lower envelope of the data, respectively, and, excluding outliers, are most easily visualized using the blue kernel density clouds. 
The data and kernel density estimates for these selected geochemical discriminants are shown in Fig. 5, along with 'eyeball' best-fit lines to the top or bottom of the kernel density clouds as appropriate. In many cases (e.g. for $\mathrm{Mg \#}, \mathrm{K}_{2} \mathrm{O}$ and $\mathrm{K}_{2} \mathrm{O} / \mathrm{Na}_{2} \mathrm{O}$; Fig. 5a-c), the visual fits show inflections during the period 3.3-3.0 Ga, which again emphasise the significance of change during this period, as highlighted by the quadratic fits, the moving medians and, in particular, the change point analysis (Figs $2-4$ ). For the elements $\mathrm{Ni}, \mathrm{Ba}$ and $\mathrm{Sr}$, and for $\mathrm{Sr} / \mathrm{Y}$, these visual fits highlight a more-or-less linear increase with time (Fig. 5d-g). For the ratios $\mathrm{Zr} / \mathrm{Sm}$ and $\mathrm{La}_{\mathrm{N}} / \mathrm{Yb}_{\mathrm{N}}$ (Fig. 5h,i), more complex patterns may indicate changes that are obscured when using simple quadratic or linear fits or a moving median of the data. In many cases, in addition to the inflection (maximum or minimum) at 3.3-3.0 Ga, a second inflection is evident at ca 2.8-2.7 Ga (Fig. 5a,b,c,g,i). Importantly, even without consideration of rocks >3.6 Ga in age, for which data are scarce, the spread (range) of data at any time for many of the geochemical proxies increases towards younger samples (Fig. 5).

\subsection{Secular change in TTG compositions and the role of pressure and temperature of melting}

Our statistical evaluation of the data used in this study shows that a fundamental change in TTG compositions occurred during the period 3.3-3.0 Ga. This period corresponds with an inferred maximum in upper mantle temperatures based on other petrological data and thermal modelling (Herzberg et al., 2010; Labrosse and Jaupart, 2007; Putirka, 2016), which is inferred by some to overlap with, or have been preceded by, a major episode of plume activity and/or a mantle overturn event (Griffin et al., 2014; Smithies et al., 2018). 
Of the major oxide/trace element compositions and/or ratios exhibiting maxima or minima, some are taken to be of particular petrogenetic significance. The $\mathrm{K}_{2} \mathrm{O} / \mathrm{Na}_{2} \mathrm{O}$ ratio, which is low in TTGs due to their origin as melts derived from mafic precursors, is inversely proportional to the degree of partial melting of the hydrated mafic source rocks (Johnson et al., 2017). Thus, the apparent minimum in $\mathrm{K}_{2} \mathrm{O} / \mathrm{Na}_{2} \mathrm{O}$ at $c a 3.3 \mathrm{Ga}$ (Fig. 2h, Fig. 5c) could be interpreted to reflect a temperature maximum.

Of the trace elements, $\mathrm{Sr} / \mathrm{Y}, \mathrm{Nb}$ and $\mathrm{Nb} / \mathrm{Ta}$ reflect the combined role of garnet (which sequesters $\mathrm{Y}$ ), plagioclase (which sequesters $\mathrm{Sr}$ ), rutile and $\mathrm{Ti}-\mathrm{Fe}$ oxides (which sequester $\mathrm{Ti}, \mathrm{Nb}$ and $\mathrm{Ta}$ and, in the case of rutile, partitions $\mathrm{Nb}$ from $\mathrm{Ta}$ ) and hornblende (which preferentially sequesters $\mathrm{Nb}$ over $\mathrm{Ta}$, affecting the $\mathrm{Nb} / \mathrm{Ta}$ ratio), which are mostly used to infer the pressure (and depth) of melting (Bédard, 2006; Foley et al., 2002; Moyen, 2011). Coinciding with the minimum values of $\mathrm{K}_{2} \mathrm{O} / \mathrm{Na}_{2} \mathrm{O}$ at $c a 3.3 \mathrm{Ga}$ : (i) the moving median for $\mathrm{Sr} / \mathrm{Y}$ shows a sharp increase from minimum values around $3.35 \mathrm{Ga}$ to much higher values from $c a 3.3 \mathrm{Ga}$ to $c a 3.15$ $\mathrm{Ga}$; (ii) the moving median for $\mathrm{La}_{\mathrm{N}} / \mathrm{Yb}_{\mathrm{N}}$ reaches a minimum at $c a 3.2 \mathrm{Ga}$; and, (iii) the quadratic fit for $\mathrm{Nb} / \mathrm{Ta}$ defines a minimum between 3.3 and $3.2 \mathrm{Ga}$ (the variability of the moving median for $\mathrm{Nb} / \mathrm{Ta}$ is a function of the scarcity of data). Combined, these data could be interpreted to reflect, on average, an increase in the depth of melting, to depths where rutile was stable, the mode of garnet was higher in the residue, and plagioclase had become relatively scarce. Although consistent with higher pressures, elevated $\mathrm{Sr} / \mathrm{Y}$ values could also reflect increased consumption of plagioclase in melting reactions due to higher temperatures, more Sr-enriched source rocks and/or increased fluid influx (i.e 'wet' melting), and lower $\mathrm{Nb} / \mathrm{Ta}$ ratios may reflect a greater abundance of hornblende in the source rocks (and melt residues). Thus, changes in petrogenetically important geochemical proxies in the interval 3.3-3.0 Ga are consistent with 
both higher pressure and temperature, and are not necessarily indicative of any particular tectonic setting.

For many of the geochemical discriminants investigated, the density clouds of data show inflections at 2.8-2.7 Ga (Fig. 5). This period correlates with a peak in the abundance of measured zircon ages (Condie and Aster, 2010; Roberts and Spencer, 2014), which has been interpreted by some to record a major pulse in the production of continental crust due to an increase in plume activity and/or a mantle overturn event at this time (Griffin et al., 2014; Smithies et al., 2018). Alternatively, during this period TTGs could have been derived from 'contaminated' source rocks that were modified by earlier subduction-like events (Sizova et al., 2015), rather than having been produced directly in association with subduction. However, for this period we note that the dataset used in this study is dominated by samples from the Superior craton (Fig. 1), and thus the inflections shown in Fig. 5 may simply reflect a local rather than a global event. Finally, the interval 2.8-2.7 Ga coincides with a major change in the rate of survival of metamorphic rocks with contrasting thermal gradients (Brown and Johnson, 2018). This may indicate that Neoarchean TTGs were related to the emergence of more compositionally evolved ( $\mathrm{Si}, \mathrm{K}$ and $\mathrm{Zr}$-rich) granitic continental arc magmas that were both more likely to saturate in $\mathrm{Zr}$ during crystallisation and have an increased preservation potential during collisional orogenesis (Cawood et al., 2013; Hawkesworth et al., 2018). This is consistent with a modest but statistically significant fall in $T_{\mathrm{Zr}}$ with decreasing age.

\subsection{The emergence of global plate tectonics}


A growing body of petrological and geochemical (including isotopic) evidence from diverse datasets has been interpreted to indicate the widespread appearance of subduction in the Mesoarchean, ultimately leading to stabilisation of the lithosphere and a globally linked network of plate boundaries (i.e. plate tectonics) by the end of the Archaean (Bercovici and Ricard, 2014; Brown and Johnson, 2018; Dhuime et al., 2012, 2015, 2017; Griffin et al., 2014; Hawkesworth and Brown, 2018; Moyen and Laurent, 2017; Naeraa et al., 2012; Smithies, 2018; Van Kranendonk et al., 2015b). For the TTG dataset discussed here, we have emphasised a statistical approach that has identified clearly the importance of some fundamental change across the interval 3.3-3.0 Ga, which is particularly clear in the change point analysis (Fig. 4).

The emergence of global plate tectonics is likely to have been a manifestation of secular cooling of the upper mantle after 3.0 Ga. In a mobile lid regime, which may have become global during the Neoarchaean, continental crust is more likely to have been produced in association with subduction. As a result, during the late Archaean, when upper mantle temperatures were significantly warmer than at present, TTGs may have been produced from direct melting of the hydrated basaltic crust at the top of the downgoing slab, in a similar manner to that proposed for the production of some adakites on the contemporary Earth. Such a mechanism implies a mantle contribution as the slab melts traverse the mantle wedge, consistent with the data for MgO (Fig. 2d), Ni (Fig. 3a) and Cr (not shown). These geochemical discriminants all increase with decreasing age, consistent with secular cooling driving melting of the downgoing slab to successively deeper levels, thereby allowing the TTG melts/magmas to interact with a greater thickness of mantle wedge on ascent (Martin and Moyen, 2002; Smithies, 2000). The correlation between these discriminants and Ba suggests some form of fluxed melting. Although this may be consistent with an increasing contribution from the mantle wedge, it may also indicate an 
increasing role for remelting of a modified lithospheric mantle component, for which subduction is not required (Bédard, 2018).

If the period 3.3-3.0 Ga marks a transition to the start of secular cooling of the upper mantle and the eventual emergence of global plate tectonics, an increase in the depth of melting of the downgoing slab with time should result in an increase in appropriate pressure/depthsensitive geochemical proxies. Notably, the upper bounds of the data density clouds for $\mathrm{La}_{\mathrm{N}} / \mathrm{Yb} \mathrm{b}_{\mathrm{N}}, \mathrm{Sr} / \mathrm{Y}$ and $\mathrm{Sr}$, which should increase with depth due to the enhanced stability of garnet and reduced stability of plagioclase (Moyen, 2011), all increase with decreasing age (Fig. 5f-h). Moreover, the moving medians for these discriminants increase from 3.2-3.1 Ga to $c a 2.9 \mathrm{Ga}$ or younger (in the case of $\mathrm{Sr}$ ), although both $\mathrm{La}_{\mathrm{N}} / \mathrm{Yb}_{\mathrm{N}}$ and $\mathrm{Sr} / \mathrm{Y}$ decline after $2.9 \mathrm{Ga}$, possibly as a result of a postulated mantle plume/overturn event at 2.8-2.7 Ga (Griffin et al., 2014; Smithies et al., 2018).

Notwithstanding that the plot of $\mathrm{Zr} / \mathrm{Sm}$ versus age shows no simple statistically meaningful fit, the moving median for these data decline with time, as does the lower bound to the kernel density cloud (Fig. 3h; Fig. 5i). The large majority of data points with values below primitive mantle (16 of 18) are Neoarchaean in age, although these data exhibit a very large spread (Fig. 3h). Sub-primitive mantle values of $\mathrm{Zr} / \mathrm{Sm}$ are characteristic of island arc basalts (Foley et al., 2002; their fig. 1a). Given that the composition of TTGs in part reflects that of their source rocks, such primitive values are consistent with a significantly increased role for subduction, or for subduction-modified sources, in the genesis of TTGs after $2.8 \mathrm{Ga}$.

Lastly, subduction-related basalts on the modern Earth are associated with $\mathrm{Th} / \mathrm{Nb}$ ratios that are elevated relative to those from within-plate settings (Pearce, 2008). Although $\mathrm{Th} / \mathrm{Nb}$ ratios show a broad continuum in magmatic rocks of Archaean age (Moyen and Laurent, 2018), and 
such 'arc-like' signatures must be treated with caution when ascribing particular tectonic settings to Archaean rocks (Johnson et al., 2017; Pearce, 2008), for Archaean TTGs this ratio shows minimum values between 3.3 and $3.0 \mathrm{Ga}$ (Fig. 3i) that might reflect a preponderance of withinplate basaltic source rocks at this time. A similar feature is shown on a plot of $\mathrm{Th} / \mathrm{Nb}$ ratios from 3.8-2.7 Ga (predominantly) mafic rocks (fig. 4 of Hawkesworth et al., 2018), in which low $\mathrm{Nb} / \mathrm{Th}$ ratios from 3.5 to $3.0 \mathrm{Ga}$ are dominated by data from the Pilbara craton, with a single datum from Barberton. Although the TTG data presented here considers more localities, the 3.63.1 Ga data are dominated by samples from the Pilbara and Kaapvaal cratons (Fig. 1). Thus, whether or not the $\mathrm{Th} / \mathrm{Nb}$ ratios of Archaean TTG record a local rather than global signature is equivocal.

In summary, data from this study and elsewhere indicate that the first two billion years of Earth's history were marked by fundamental changes culminating in a transition from a deformable stagnant lid, probably with localised episodes of 'proto-subduction', to some form of global plate tectonic (mobile lid) geodynamic regime (Bédard, 2018; Bercovici and Ricard, 2014; Hawkesworth and Brown, 2018; Sizova et al., 2015). During this period, the crust likely evolved from one that was dominantly mafic in the Hadean and Eoarchaean (O'Neil and Carlson, 2017; Reimink et al., 2016; Tang et al., 2016) to one that was more differentiated in the Neoarchaean. It has been argued elsewhere that the first voluminous TTG magmas formed at the base of increasingly thick plateau-like units of mafic crust in the late Eoarchean to Paleoarchean, leading to stabilisation of the first ancient continental nuclei (Johnson et al., 2017). Growth of first generation continental crust continued as mantle temperatures reached a peak in the late Paleoarchean to Mesoarchean. Thereafter, cooling of the upper mantle led eventually to the widespread appearance of subduction and the emergence of global plate tectonics. The modern 
style of plate tectonics, which is characterised by cold collision and deep subduction of continental crust, did not begin until the Neoproterozic (Brown and Johnson, 2018).

\subsection{The irreversible differentiation of the lithosphere}

Other than the evidence for a significant change across the interval 3.3-3.0 Ga, perhaps the most striking feature of the data is the increase in compositional variability with time, which is particularly clear by visual inspection of the data density clouds for $\mathrm{Al}_{2} \mathrm{O}_{3}, \mathrm{MgO}, \mathrm{K} 2 \mathrm{O}, \mathrm{Ni}, \mathrm{Ba}$, $\mathrm{Sr}, \mathrm{Eu} / \mathrm{Eu}^{*}, \mathrm{Nb} / \mathrm{Ta}, \mathrm{Sr} / \mathrm{Y}$ and $\mathrm{Zr} / \mathrm{Sm}$ (Fig. 5). The notable increase in the spread of data with time is consistent with a greater degree of reworking of pre-existing crustal rocks (Gardiner et al., 2017). Thus, we interpret these observations to indicate that the compositional range of hydrated basaltic TTG source rocks increased with time, and that early formed TTGs may have remelted to produce more granitic melts leaving behind plagioclase-and hornblende-rich residua. This suggestion is consistent with the decrease in $\mathrm{Zr}_{\mathrm{T}}$ with time and the increase in preserved zircon in the Neoarchean.

\section{Conclusions}

Interrogation of a global database of TTG magmatic rocks interpreted to represent first generation Archaean continental crust (i.e. derived from the partial melting of hydrated metabasic rocks) reveals the following: 
(i) Although the data exhibit a high degree of scatter, the concentrations or ratios of several key major oxide and trace elements show statistically significant trends that indicate maxima, minima and/or transitions in the interval 3.3-3.0 Ga. Importantly, a change point analysis of $\mathrm{K}_{2} \mathrm{O} / \mathrm{Na}_{2} \mathrm{O}, \mathrm{Sr} / \mathrm{Y}$ and $\mathrm{La}_{\mathrm{N}} / \mathrm{Yb}_{\mathrm{N}}$ demonstrates a statistically significant (>99\% confidence) change during the period 3.3-3.0 Ga.

(ii) The period 3.3-3.0 Ga coincides with an inferred peak in upper mantle temperatures such that the fundamental change in geodynamic regime may be linked to the onset of secular cooling of the mantle. Although any link between chemical composition and geodynamic regime is tenuous for the Archaean, our results are consistent with other studies.

(iii) Another notable change at 2.8-2.7 Ga may relate to the emergence of more potassic continental arc magmas and an increased preservation potential during collisional orogenesis.

(iv) The chemical composition of TTGs shows an increasing spread through the Archaean, reflecting the irreversible differentiation of the lithosphere.

\section{Acknowledgements}

We thank C. Hawkesworth and an anonymous reviewer for their insightful comments and F. Moynier for his editorial handling. R.H. Smithies publishes with the permission of the executive director of the Geological Survey of Western Australia. 


\section{References}

Arndt, N., 2013. Formation and Evolution of the Continental Crust. Geochemical Perspectives 2, 405-533.

Baker, M., 2016. Statisticians issue warning on P values. Nature 531, 151-151.

Bédard, J.H., 2006. A catalytic delamination-driven model for coupled genesis of Archaean crust and sub-continental lithospheric mantle. Geochim. Cosmochim. Acta 70, 1188-1214.

Bédard, J.H., 2018. Stagnant lids and mantle overturns: implications for Archaean tectonics, magmagenesis, crustal growth, mantle evolution, and the start of plate tectonics. Geosci. Front. 9, 19-49.

Belousova, E.A., Kostitsyn, Y.A., Griffin, W.L., Begg, G.C., O'Reilly, S.Y., Pearson, N.J., 2010. The growth of the continental crust: Constraints from zircon Hf-isotope data. Lithos 119, 457-466.

Bercovici, D., Ricard, Y., 2014. Plate tectonics, damage and inheritance. Nature 508, 513.

Boehnke, P., Watson, E.B., Trail, D., Harrison, T.M., Schmitt, A.K., 2013. Zircon saturation rerevisited. Chem. Geol. 351, 324-334.

Brown, M., Johnson, T., 2018. Secular change in metamorphism and the onset of global plate tectonics. Am. Mineral. 103, 181-196.

Calvert, A., Sawyer, E., Davis, W., Ludden, J., 1995. Archaean subduction inferred from seismic images of a mantle suture in the Superior Province. Nature 375, 670. 
Cawood, P.A., Hawkesworth, C.J., Dhuime, B., 2013. The continental record and the generation of continental crust. Bulletin of the Geological Society of America 125, 14-32.

Cawood, P.A., Kröner, A., Pisarevsky, S., 2006. Precambrian plate tectonics: Criteria and evidence. GSA Today 16, 4-11.

Condie, K.C., Aster, R.C., 2010. Episodic zircon age spectra of orogenic granitoids: The supercontinent connection and continental growth. Precambr. Res. 180, 227-236.

Condie, K.C., Aster, R.C., van Hunen, J., 2016. A great thermal divergence in the mantle beginning $2.5 \mathrm{Ga}$ : geochemical constraints from greenstone basalts and komatiites. Geosci. Front. 7, 543-553.

Condie, K.C., Puetz, S.J., Davaille, A., 2018. Episodic crustal production before 2.7 Ga. Precambr. Res. 312, 16-22.

de Wit, M., Furnes, H., MacLennan, S., Doucouré, M., Schoene, B., Weckmann, U., Martinez, U., Bowring, S., 2018. Paleoarchean bedrock lithologies across the Makhonjwa Mountains of South Africa and Swaziland linked to geochemical, magnetic and tectonic data reveal early plate tectonic genes flanking subduction margins. Geosci. Front. 9, 603-665.

Dhuime, B., Hawkesworth, C.J., Cawood, P.A., Storey, C.D., 2012. A change in the geodynamics of continental growth 3 billion years ago. Science 335, 1334-1336.

Dhuime, B., Hawkesworth, C.J., Delavault, H., Cawood, P.A., 2017. Continental growth seen through the sedimentary record. Sedimentary Geology.

Dhuime, B., Wuestefeld, A., Hawkesworth, C.J., 2015. Emergence of modern continental crust about 3 billion years ago. Nat. Geosci. 8, 552-555. 
Drummond, M.S., Defant, M.J., 1990. A model for trondhjemite-tonalite-dacite genesis and crustal growth via slab melting: Archean to modern comparisons. Journal of Geophysical Research 95, 21,503-521,521.

Foley, S., Tiepolo, M., Vannucci, R., 2002. Growth of early continental crust controlled by melting of amphibolite in subduction zones. Nature 417, 837-840.

Friend, C.R.L., Nutman, A.P., 2005. New pieces to the Archaean terrane jigsaw puzzle in the Nuuk region, southern West Greenland: Steps in transforming a simple insight into a complex regional tectonothermal model. Journal of the Geological Society 162, 147-162.

Garde, A.A., 1997. Accretion and evolution of an Archaean high-grade grey gneiss-amphibolite complex: the Fiskefjord area, southern (West Greenland). Geology of Greenland Survey Bulletin 177.

Gardiner, N.J., Hickman, A.H., Kirkland, C.L., Lu, Y., Johnson, T., Zhao, J.-X., 2017. Processes of Crust Formation in the Early Earth Imaged through Hf isotopes from the East Pilbara Terrane. Precambr. Res.

Griffin, W.L., Belousova, E.A., O'Neill, C., O'Reilly, S.Y., Malkovets, V., Pearson, N.J., Spetsius, S., Wilde, S.A., 2014. The world turns over: Hadean-Archean crust-mantle evolution. Lithos 189, 2-15.

Hawkesworth, C., Cawood, P.A., Dhuime, B., 2018. Rates of generation and growth of the continental crust. Geosci. Front. xx, xxx-xxx.

Hawkesworth, C.J., Brown, M., 2018. Earth dynamics and the development of Plate Tectonics. Philosophical Transactions of the Royal Society A: Mathematical, Physical and Engineering Sciences $\mathrm{xx}, \mathrm{xxx}-\mathrm{xxx}$. 
Hawkesworth, C.J., Dhuime, B., Pietranik, A.B., Cawood, P.A., Kemp, A.I.S., Storey, C.D., 2010. The generation and evolution of the continental crust. Journal of the Geological Society $167,229-248$.

Herzberg, C., Asimow, P.D., Arndt, N., Niu, Y., Lesher, C., Fitton, J., Cheadle, M., Saunders, A., 2007. Temperatures in ambient mantle and plumes: Constraints from basalts, picrites, and komatiites. Geochem. Geophys. Geosyst. 8.

Herzberg, C., Condie, K., Korenaga, J., 2010. Thermal history of the Earth and its petrological expression. Earth. Planet. Sci. Lett. 292, 79-88.

Hoffmann, J.E., Münker, C., Næraa, T., Rosing, M.T., Herwartz, D., Garbe-Schönberg, D., Svahnberg, H., 2011. Mechanisms of Archean crust formation inferred from high-precision HFSE systematics in TTGs. Geochim. Cosmochim. Acta 75, 4157-4178.

Hoffmann, J.E., Nagel, T.J., Münker, C., Næraa, T., Rosing, M.T., 2014. Constraining the process of Eoarchean TTG formation in the Itsaq Gneiss Complex, southern West Greenland. Earth. Planet. Sci. Lett. 388, 374-386.

Jenner, F.E., Bennett, V.C., Nutman, A.P., Friend, C.R.L., Norman, M.D., Yaxley, G., 2009. Evidence for subduction at $3.8 \mathrm{Ga}$ : Geochemistry of arc-like metabasalts from the southern edge of the Isua Supracrustal Belt. Chem. Geol. 261, 82-97.

Johnson, T.E., Brown, M., Gardiner, N.J., Kirkland, C.L., Smithies, R.H., 2017. Earth's first stable continents did not form by subduction. Nature.

Johnson, T.E., Brown, M., Kaus, B.J.P., Vantongeren, J.A., 2014. Delamination and recycling of archaean crust caused by gravitational instabilities. Nat. Geosci. 7, 47-52.

Kamber, B.S., 2015. The evolving nature of terrestrial crust from the Hadean, through the Archaean, into the Proterozoic. Precambr. Res. 258, 48-82. 
Keller, C.B., Schoene, B., 2012. Statistical geochemistry reveals disruption in secular lithospheric evolution about 2.5 Gyr ago. Nature 485, 490-493.

Korenaga, J., 2013. Archean Geodynamics and the Thermal Evolution of Earth, Archean Geodynamics and Environments, pp. 7-32.

Kusky, T., Polat, A., Windley, B.F., Burke, K., Dewey, J., Kidd, W., Maruyama, S., Wang, J., Deng, H., Wang, Z., 2016. Insights into the tectonic evolution of the North China Craton through comparative tectonic analysis: A record of outward growth of Precambrian continents. Earth-Science Reviews 162, 387-432.

Labrosse, S., Jaupart, C., 2007. Thermal evolution of the Earth: Secular changes and fluctuations of plate characteristics. Earth. Planet. Sci. Lett. 260, 465-481.

Martin, H., 1999. Adakitic magmas: Modern analogues of Archaean granitoids. Lithos 46, 411429.

Martin, H., Moyen, J.-F., 2002. Secular changes in tonalite-trondhjemite-granodiorite composition as markers of the progressive cooling of Earth. Geology 30, 319-322.

McDonough, W.F., Sun, S.-S., 1995. The composition of the Earth. Chem. Geol. 120, 223-253.

Moyen, J.-F., Laurent, O., 2017. Archaean tectonic systems: A view from igneous rocks. Lithos. Moyen, J.F., 2011. The composite Archaean grey gneisses: Petrological significance, and evidence for a non-unique tectonic setting for Archaean crustal growth. Lithos 123, 21-36.

Mustonen, A.-M., Lempiäinen, T., Aspelund, M., Hellstedt, P., Ikonen, K., Itämies, J., Vähä, V., Erkinaro, J., Asikainen, J., Kunnasranta, M., Niemelä, P., Aho, J., Nieminen, P., 2012. Application of change-point analysis to determine winter sleep patterns of the raccoon dog (Nyctereutes procyonoides) from body temperature recordings and a multi-faceted dietary and behavioral study of wintering. BMC Ecology 12, 27. 
Naeraa, T., Schersten, A., Rosing, M.T., Kemp, A.I., Hoffmann, J.E., Kokfelt, T.F., Whitehouse, M.J., 2012. Hafnium isotope evidence for a transition in the dynamics of continental growth 3.2 Gyr ago. Nature 485, 627-630.

O'Neil, J., Carlson, R.W., 2017. Building Archean cratons from Hadean mafic crust. Science $355,1199-1202$.

O'Neil, J., Francis, D., Carlson, R.W., 2011. Implications of the Nuvvuagittuq Greenstone Belt for the Formation of Earth's Early Crust. J. Petrol. 52, 985-1009.

Pearce, J.A., 2008. Geochemical fingerprinting of oceanic basalts with applications to ophiolite classification and the search for Archean oceanic crust. Lithos 100, 14-48.

Polat, A., Wang, L., Appel, P.W.U., 2015. A review of structural patterns and melting processes in the Archean craton of West Greenland: Evidence for crustal growth at convergent plate margins as opposed to non-uniformitarian models. Tectonophysics 662, 67-94.

Putirka, K., 2016. Rates and styles of planetary cooling on Earth, Moon, Mars, and Vesta, using new models for oxygen fugacity, ferric-ferrous ratios, olivine-liquid Fe-Mg exchange, and mantle potential temperature. Am. Mineral. 101, 819-840.

Reimink, J.R., Davies, J.H.F.L., Chacko, T., Stern, R.A., Heaman, L.M., Sarkar, C., Schaltegger, U., Creaser, R.A., Pearson, D.G., 2016. No evidence for Hadean continental crust within Earth's oldest evolved rock unit. Nat. Geosci. 9, 777-780.

Roberts, N.M.W., Spencer, C.J., 2014. The zircon archive of continent formation through time. Geological Society, London, Special Publications 389.

Rozel, A., Golabek, G., Jain, C., Tackley, P., Gerya, T., 2017. Continental crust formation on early Earth controlled by intrusive magmatism. Nature 545, 332. 
Santosh, M., Yang, Q.-Y., Shaji, E., Tsunogae, T., Mohan, M.R., Satyanarayanan, M., 2015. An exotic Mesoarchean microcontinent: the Coorg Block, southern India. Gondwana Research 27, 165-195.

Sizova, E., Gerya, T., Stüwe, K., Brown, M., 2015. Generation of felsic crust in the Archean: A geodynamic modeling perspective. Precambr. Res. 271, 198-224.

Smithies, R.H., 2000. The Archaean tonalite-trondhjemite-granodiorite (TTG) series is not an analogue of Cenozoic adakite. Earth. Planet. Sci. Lett. 182, 115-125.

Smithies, R.H., Champion, D.C., Cassidy, K.F., 2003. Formation of Earth's early Archaean continental crust. Precambr. Res. 127, 89-101.

Smithies, R.H., Ivanic, T.J., Lowrey, J.R., Morris, P.A., Barnes, S.J., Wyche, S., Lu, Y.-J., 2018. Two distinct origins for Archean greenstone belts. Earth. Planet. Sci. Lett. 487, 106-116.

Smithies, R.H., Van Kranendonk, M.J., Champion, D.C., 2007. The Mesoarchean emergence of modern-style subduction. Gondwana Research 11, 50-68.

Smithies, R.H.I., T. J.; Lowrey, J. R.; Morris, P. A.; Barnes, S. J.; Wyche, S.; Yong-Jun, L, 2018. Two distinct origins for Archean greenstone belts. Earth. Planet. Sci. Lett. XX, xxx-xxx.

Sun, S.s., McDonough, W.F., 1989. Chemical and isotopic systematics of oceanic basalts: implications for mantle composition and processes. Geological Society, London, Special Publications 42, 313-345.

Tang, M., Chen, K., Rudnick, R.L., 2016. Archean upper crust transition from mafic to felsic marks the onset of plate tectonics. Science 351, 372-375.

Turner, S., Rushmer, T., Reagan, M., Moyen, J.F., 2014. Heading down early on? Start of subduction on Earth. Geology 42, 139-142. 
Van Kranendonk, M.J., Hugh Smithies, R., Griffin, W.L., Huston, D.L., Hickman, A.H., Champion, D.C., Anhaeusser, C.R., Pirajno, F., 2015a. Making it thick: A volcanic plateau origin of Palaeoarchean continental lithosphere of the Pilbara and Kaapvaal cratons, Geological Society Special Publication, pp. 83-111.

Van Kranendonk, M.J., Kirkland, C.L., Cliff, J., 2015b. Oxygen isotopes in Pilbara Craton zircons support a global increase in crustal recycling at 3.2Ga. Lithos 228-229, 90-98.

Walzer, U., Hendel, R., 2013. Real episodic growth of continental crust or artifact of preservation? A 3-D geodynamic model. Journal of Geophysical Research: Solid Earth $118,2356-2370$. 


\section{Figure captions}

Fig. 1. Histogram (0.02 Gyr bin width) and probability curve (0.02 Gyr bandwidth) for the magmatic ages of the 563 TTG samples used in this study (Supplementary Data Table 1) plotted against age. The samples are colour-coded by craton/cratonic fragment. NAC $=$ North Atlantic Craton.

Fig. 2. Plots of selected major oxides (as weight \%) and major oxide ratios (as logarithmic values) versus age. Individual data points are superimposed on smoothed kernel density estimates (blue 'clouds'). The solid black lines show quadratic fits where these are considered to be statistically significant. The dotted black lines show simple linear fits in cases where the quadratic fits are not statistically meaningful. In both cases the white bands show the mean

prediction bands calculated at a 95\% confidence level. Solid red lines show moving medians and dashed red lines show the upper fence, both of which are calculated every 20 million years using a 0.2 Ga moving window.

Fig. 3. Plots of selected trace elements (as parts per million, ppm) and trace element ratios (as logarithmic values, some normalised against CI chondrite) versus age. Individual data points are superimposed on smoothed kernel density estimates (blue 'clouds'). The solid black lines show quadratic fits where these are considered to be statistically significant. The dotted black lines show simple linear fits in cases where the quadratic fits are not statistically meaningful. In both cases the white bands show the mean prediction bands calculated at a $95 \%$ confidence level. Where neither quadratic nor linear fits are statistically meaningful, no fit is shown. Solid red 
lines show moving medians and dashed red lines show the upper fence, both of which are calculated every 20 million years using a $0.2 \mathrm{Ga}$ moving window.

Fig. 4. Cumulative sum (CUSUM) change-point analysis for selected geochemical proxies. Note that the time axis is non-linear and a function of the density of data within particular time intervals. For all the proxies shown here, abrupt shifts are evident in the period 3.0-3.3 Ga.

Fig. 5. Plots of selected geochemical data, showing individual data points superimposed on smoothed kernel density estimates (blue 'clouds'). The red lines are 'eyeballed' best-fit lines to the top or bottom of the kernel density clouds based on whether the proxy would be depleted or enriched in the magma by fractional crystallisation of hornblende and plagioclase. The grey bands highlight the period 3.3-3.0 Ga that is argued to record a fundamental transition (see text and Figs 2-4). 


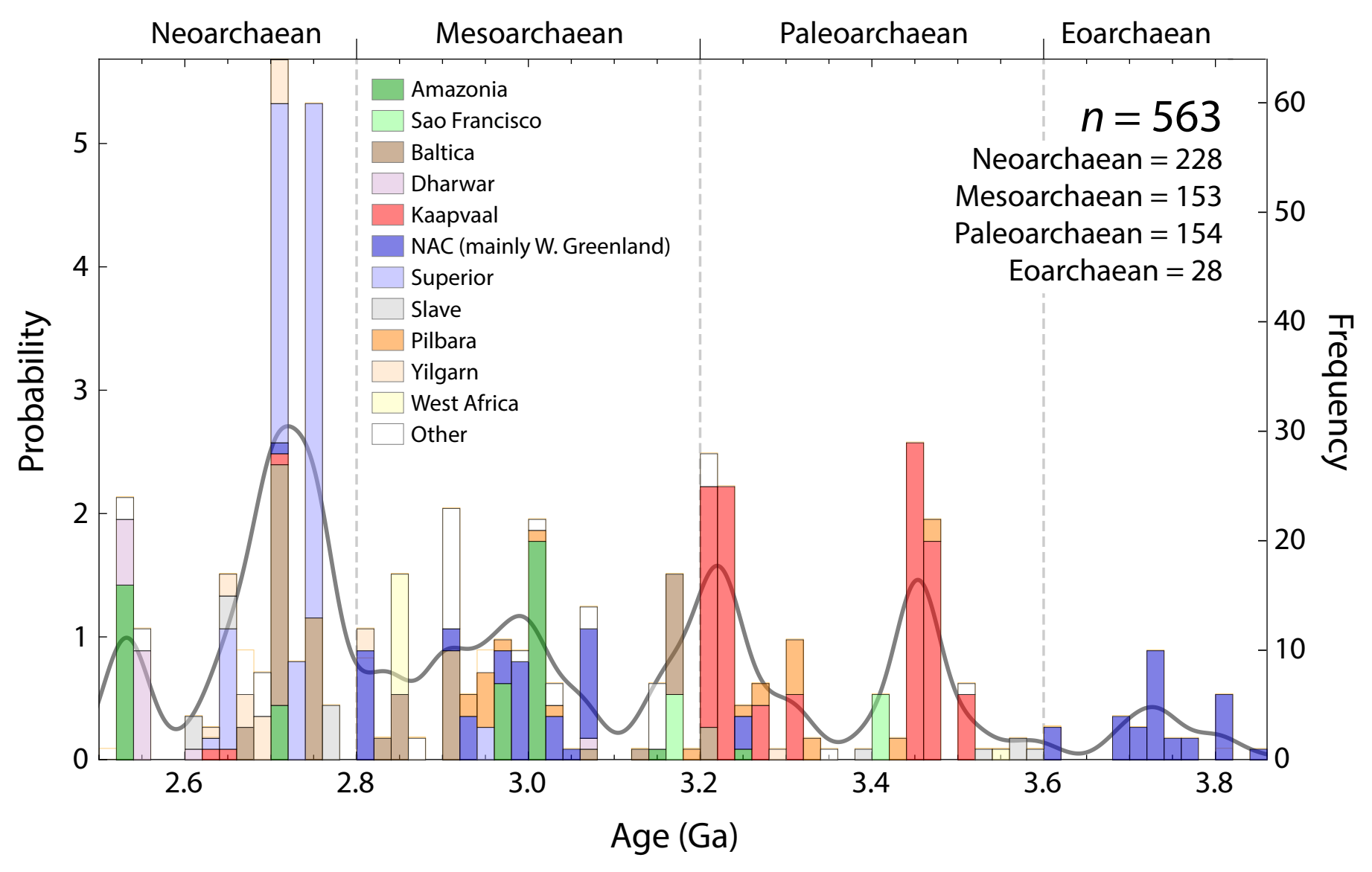

Johnson et al. Figure 1 

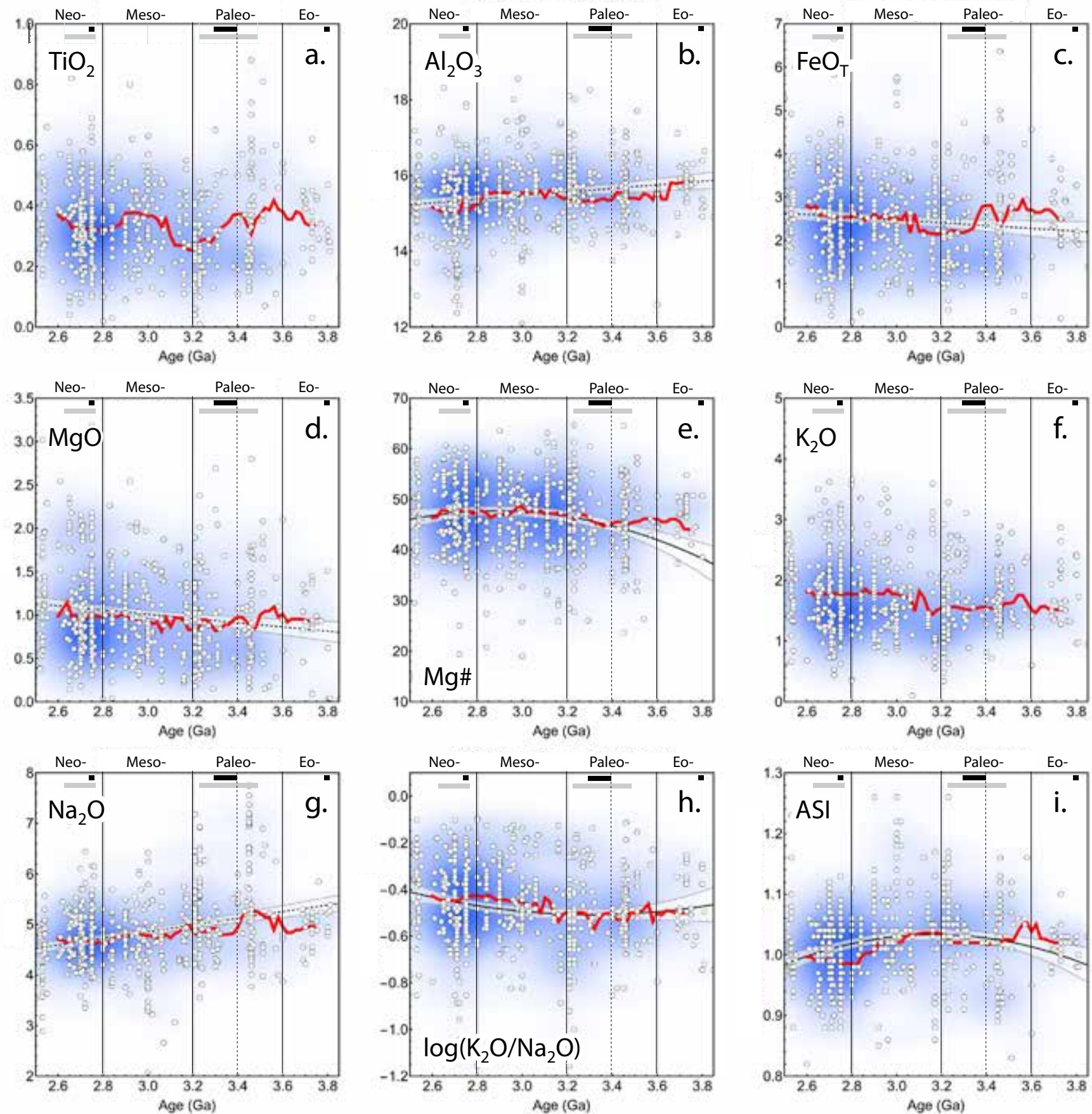

Johnson et al. Figure 2 

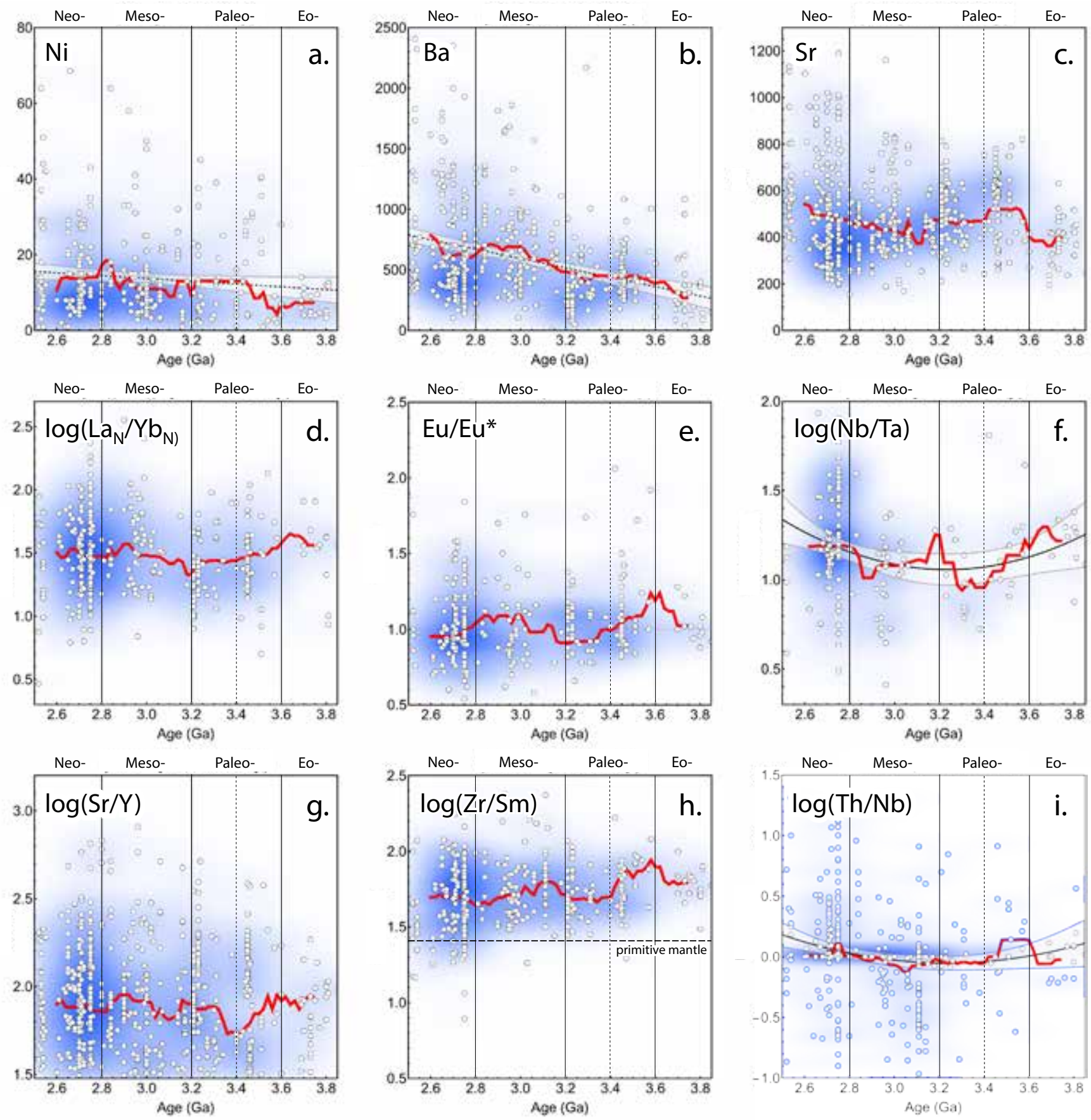

\section{Johnson et al. Figure 3}



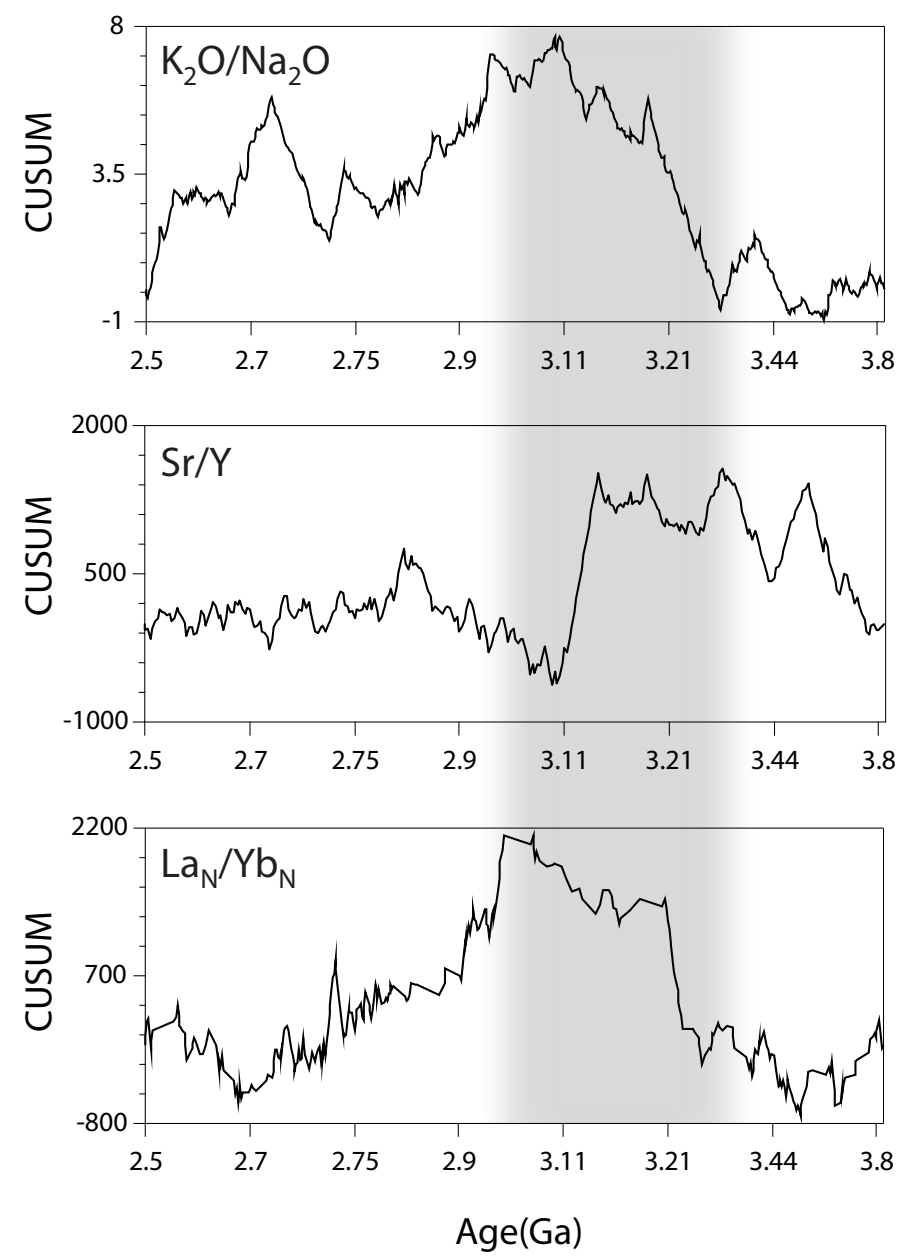

Johnson et al. Figure 4 

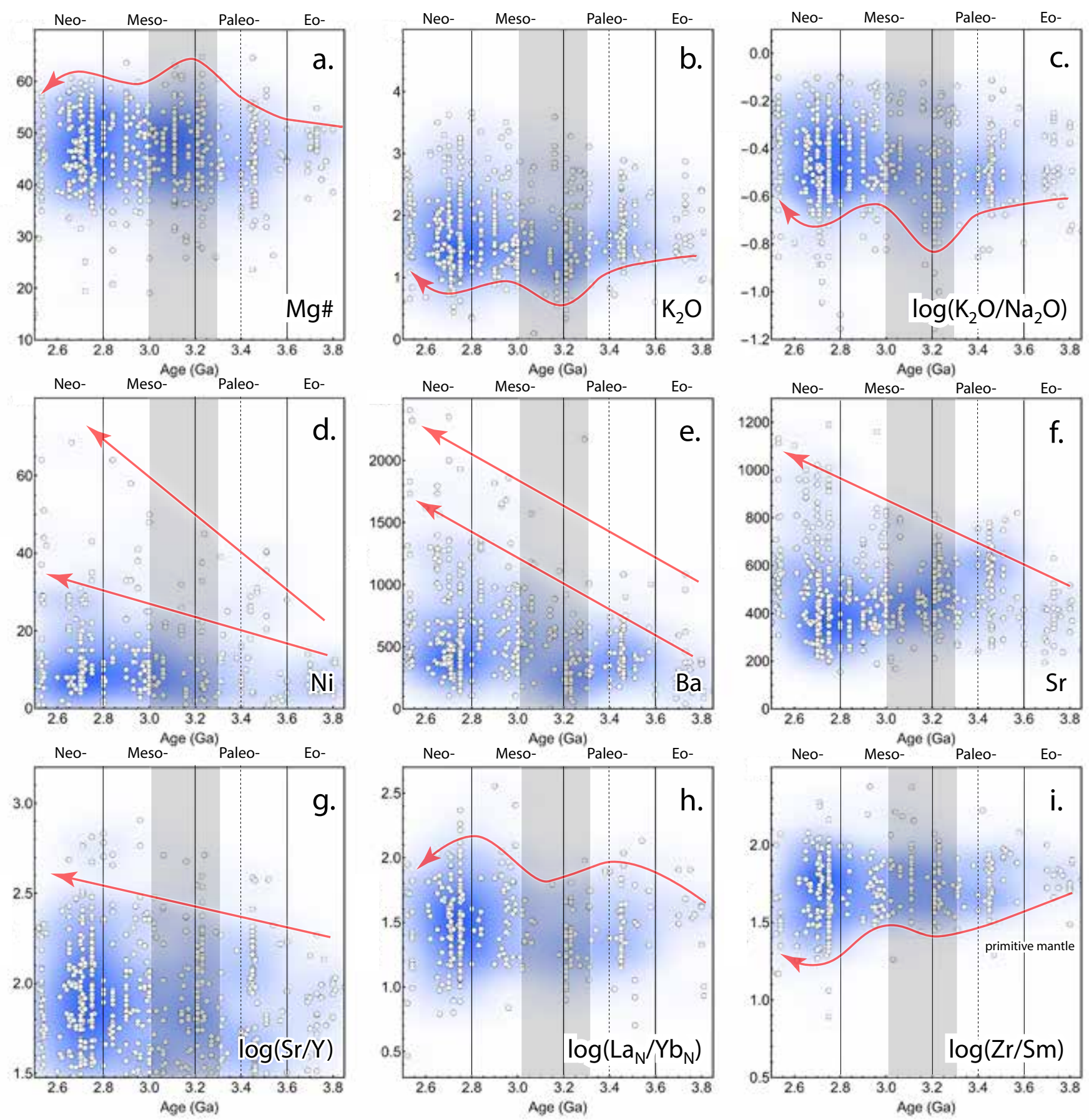

Johnson et al. Figure 5 

Supplementary material for online publication only
Click here to download Supplementary material for

Click here to download Supplementary material for online publication only: Supp_data.xlsx

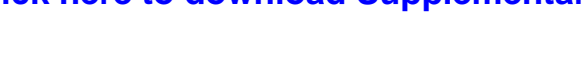
.

tor

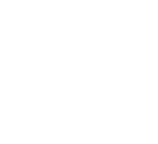

$\sqrt{3}$

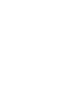

(1) (1) . . . . . . . . . . . . . . . . 